\title{
Reducing nitrous oxide emissions from grazed winter forage crops
}

\author{
T.J. VAN DER WEERDEN and T.M. STYLES \\ Agresearch, Invermay Agricultural Centre, Private Bag 50034, Mosgiel 9053, New Zealand \\ tony.vanderweerden@agresearch.co.nz
}

\begin{abstract}
Wintering cows on forage crops leads to urine being excreted onto wet, compacted soils. This is likely to result in significant gaseous emissions of nitrous oxide $\left(\mathrm{N}_{2} \mathrm{O}\right)$, which may be reduced through strategic applications of nitrification inhibitors. A study was established on a winter swede crop to (i) determine $\mathrm{N}_{2} \mathrm{O}$ emissions from compacted soil treated with cattle urine, and (ii) quantify the effectiveness of a nitrification inhibitor, dicyandiamide (DCD), in reducing these emissions. Nitrous oxide emissions from the urine + compacted soil were significantly greater $(\mathrm{P}<0.001)$ than from compacted soil without urine, with $3.2 \%$ of the urine- $\mathrm{N}$ being lost as $\mathrm{N}_{2} \mathrm{O}$. DCD application significantly reduced this loss $(\mathrm{P}<0.05)$ to $0.8 \%$ of the applied urine-N. Expressed at a paddock scale, total $\mathrm{N}_{2} \mathrm{O}$ emissions from the winter-grazed swede crop were $7.9 \mathrm{~kg} \mathrm{~N}$ ha ${ }^{-1}$, which was reduced to $3.4 \mathrm{~kg} \mathrm{~N} \mathrm{ha}^{-1}$ when DCD was applied.
\end{abstract}

Keywords: urine, dicyandiamide, nitrification inhibitor, soil compaction, nitrous oxide.

\section{Introduction}

Dairy farmers are under increasing pressure to alter their winter management practices to reduce associated environmental impacts. Winter grazing of brassica crops such as swedes and kale during high soil moisture conditions results in increased soil compaction, which reduces the volume of macro-pores (Houlbrooke et al. 2009). Under these anaerobic conditions, urine deposition could lead to relatively high emissions of nitrous oxide $\left(\mathrm{N}_{2} \mathrm{O}\right)$, a potent greenhouse gas with a global warming potential $c a .300$ times that of carbon dioxide over a 100-year time frame. Indeed, under pasture, compaction of soil can lead to a three-fold increase in denitrification-induced $\mathrm{N}_{2} \mathrm{O}$ emissions compared to non-compacted soils (Menneer et al. 2005; Bhandral et al. 2007). Previous research has shown that nitrification inhibitors such as dicyandiamide (DCD) directly applied to grazed pasture reduce $\mathrm{N}_{2} \mathrm{O}$ emissions from urine patches (Di et al. 2007). However, little is known about their effectiveness within a winter-grazed forage system, although one study on a Southland kale crop showed $\mathrm{N}_{2} \mathrm{O}$ emissions from an artificial urine solution were reduced by $25 \%$ with DCD application
(Smith et al. 2008). The objectives of this study were to (i) determine $\mathrm{N}_{2} \mathrm{O}$ emissions from a urine-affected winter "grazed" swede crop, and (ii) quantify the effectiveness of DCD in reducing these emissions.

\section{Methods}

\section{Soil and site description.}

The study was conducted on a poorly-drained Te Houka silt loam soil (Fragic perch-gley Pallic soil; Hewitt 2010) supporting a winter crop of swedes (Brassica napus; approx. $14 \mathrm{t} \mathrm{DM} / \mathrm{ha}$ ) in South Otago. Mean annual rainfall was $679 \mathrm{~mm}$, while mean annual air temperature was $10.4^{\circ} \mathrm{C}$. An enclosure within the swede paddock $(35 \times 20 \mathrm{~m})$ was established to ensure cattle did not disturb the study site. Two trials were established to determine $\mathrm{N}_{2} \mathrm{O}$ emissions from simulated urine patches deposited onto compacted soil. Trial 1 commenced on 15 June 2011 and included additional treatments to determine the effectiveness of DCD in reducing $\mathrm{N}_{2} \mathrm{O}$ emissions. Trial 2 commenced on 20 July. Immediately prior to the start of each trial, all swedes inside the enclosed area were removed with minimal soil disturbance.

\section{Treatments}

Trial 1 included five treatments: (i) "non-compacted" soil, (ii) "compacted" soil, (iii) "compacted + DCD", (iv) "compacted + urine" and (v) "compacted + urine + DCD". A randomised block design was used, with six replicate plots $(1 \times 2 \mathrm{~m})$ for each treatment. Trial 2 included only three of these treatments: (i) "noncompacted" soil, (ii) "compacted" soil, (iii) "compacted + urine". Each treatment was again replicated six times, apart from the "non-compacted" treatment (three reps) and the treatments were not blocked as data analysis from the earlier trial suggested no benefit from blocking. "Compacted" treatments simulated pugging - technical staff used short ( $c a .10 \mathrm{~cm}$ long) wooden blocks strapped to work boots to repeatedly apply a downward force to the soil. The footprint area of each block was based on bodyweight in order to apply a pressure of $c a .300 \mathrm{kPa}$. Care was taken to ensure the same level of compaction per area was applied to all "compacted" plots. Static chamber bases $(250 \mathrm{~mm}$ internal diameter) were inserted into the gas sampling plots following compaction treatments and left for 
one day before urine was applied. Soil sampling plots $\left(1 \mathrm{~m}^{2}\right)$ were established adjacent to the gas sampling plots, where an artificial urine solution was used to represent cow urine due to the challenges associated with collecting sufficient real cow urine.

Dairy cow urine for the gas sampling plots was collected for trials 1 and 2 on 21 June and 25 July, respectively, from cows grazing the swede crop. This had an $\mathrm{N}$ content of 1.90 and $0.85 \mathrm{~g} \mathrm{~N} / \mathrm{L}$, respectively. The $\mathrm{N}$ content of urine collected in the second sampling was increased using urea to match the concentration measured in the first sampling. Urine was applied at a rate of $10 \mathrm{~L} / \mathrm{m}^{2}$, resulting in an application rate of 190 $\mathrm{kg} \mathrm{N} / \mathrm{ha}$. An artificial urine solution with the equivalent $\mathrm{N}$ concentration was applied to the soil sampling plots. The nitrification inhibitor DCD was applied as a fine spray at a rate of $10 \mathrm{~kg} \mathrm{DCD} / \mathrm{ha}$ within 2 hours of urine application in trial 1 .

\section{$\mathrm{N}_{2} \mathrm{O}$ measurements}

$\mathrm{N}_{2} \mathrm{O}$ emissions were measured using the standard closed chamber technique (de Klein et al. 2003). The emissions were integrated over 130 and 96 days for trials 1 and 2, respectively, to estimate total emissions over the measurement period, which ceased at the end of October when the paddock was to be cultivated. Emission factors were then calculated using equation 1:

$$
E F_{3}=\frac{\text { Urine } \mathrm{N}_{2} \mathrm{O}-\text { Control } \mathrm{N}_{2} \mathrm{O}}{\text { Urine } \mathrm{N} \text { applied }} \times 100
$$

where $\mathrm{EF}_{3}$ is an emission factor $\left(\mathrm{N}_{2} \mathrm{O}-\mathrm{N}\right.$ emitted as a percentage of urine- $\mathrm{N}$ applied), Urine $\mathrm{N}_{2} \mathrm{O}$ and Control $\mathrm{N}_{2} \mathrm{O}$ are the cumulative $\mathrm{N}_{2} \mathrm{O}$ emissions from urinetreated and control plots, respectively $\left(\mathrm{kg} \mathrm{N} \mathrm{ha}^{-1}\right)$, and Urine $\mathrm{N}$ applied is in units of $\mathrm{kg} \mathrm{N} \mathrm{ha}^{-1}$. $\mathrm{EF}_{3}$ values were calculated for trial 1 on an individual block basis. In trial 2, where blocking was not employed, the average cumulative emission for non-urine treated plots was used.

Estimates of $\mathrm{N}_{2} \mathrm{O}$ emissions at a paddock scale used assumptions for $\mathrm{N}$ and water excretion by the herd of 83 cows, which grazed the 2.8 ha swede crop over a 52 day period (crop allowance of $6.6 \mathrm{~m}^{2} / \mathrm{cow} /$ day). Based on cow feed intake data and changes in body condition score (D. Stevens, unpubl. data), and allowing for $\mathrm{N}$ retention for foetus development, $\mathrm{N}$ excretion was calculated as $129 \mathrm{~g}$ urine-N/cow/day and $95 \mathrm{~g}$ dung-N/ cow/day. A water balance calculation suggested that each cow excreted, on average, $72 \mathrm{~L}$ water/day, of which $60 \mathrm{~L}$ was urine (the remainder in dung). Assuming no urine patch overlap, this translated to $c a .90 \%$ of the paddock surface being affected by urine patches. An emission factor of $0.25 \%$ was assumed to account for $\mathrm{N}_{2} \mathrm{O}$ emissions from dung excretion to the paddock (Ministry for the Environment 2012)

\section{Soil parameters}

Soil physical measurements (bulk density, macroporosity ( $>30 \mu \mathrm{m}$ diameter) and total porosity) were measured in non-compacted and compacted plots at the end of the trial. Soil mineral N and moisture contents were determined from samples collected from the $0-75 \mathrm{~mm}$ depth regularly throughout each trial. Six soil cores $(25 \mathrm{~mm}$ diameter $\times 75 \mathrm{~mm}$ depth) were collected and thoroughly mixed before a subsample was extracted with $2 M \mathrm{KCl}$ solution ( $15 \mathrm{~g}$ wet soil: 100 $\mathrm{g} \mathrm{KCl}$ ) for 1 hour. Samples were filtered using GF/A glass-fibre filter papers $(110 \mathrm{~mm})$ and frozen until mineral $\mathrm{N}$ was analysed. Soil moisture content was determined by drying soil at $105^{\circ} \mathrm{C}$ for 24 hours, with water filled pore space (WFPS, \%) calculated using bulk density data.

Results were statistically analysed by ANOVA (Genstat 13), where cumulative $\mathrm{N}_{2} \mathrm{O}$ emissions required a log transformation to determine differences between treatments.

\section{Results}

Changes in soil moisture contents, soil mineral $\mathbf{N}$ levels and soil structure

A total of $156 \mathrm{~mm}$ of rain fell during the 4-month experimental period (Fig. 1), with soil temperature (5 $\mathrm{cm}$ depth) averaging $6^{\circ} \mathrm{C}$ (range of $2-15^{\circ} \mathrm{C}$ ). With low evapo-transpiration rates over the winter months, soil moisture levels were correspondingly high in both trials, with WFPS averaging $80-100 \%$ for the first $2-3$ months (Fig. 1), before declining to $c a .50 \%$ in October, due to good drying conditions (less rainfall, increasing temperatures). Compacted soils had a significantly higher $(\mathrm{P}<0.01)$ WFPS than non-compacted soils in both trials. The WFPS of compacted soils in trial 1 was often above $100 \%$ due to surface ponding. A similar result was observed by de Klein et al. (2006). In our study, we have limited WFPS to the theoretical maximum of $100 \%$ (Fig. 1). Bulk density for the noncompacted soil was $1.00 \mathrm{~g} / \mathrm{cm}^{3}$ in the $0-5 \mathrm{~cm}$ layer and increased to $1.22 \mathrm{~g} / \mathrm{cm}^{3}$ in the $5-10 \mathrm{~cm}$ depth (Table 1). The simulated compaction significantly $(\mathrm{P}<0.01)$ increased bulk density and reduced macroporosity in the 0-5 cm layer but had no effect on the 5-10 cm depth.

In trial 1, soil mineral $\mathrm{N}$ was only measured from the three non-urine treatments due to a laboratory error when making the artificial urine solution that was applied to the soil sampling plots. Soil ammonium- $\mathrm{N}_{(}\left(\mathrm{NH}_{4}{ }^{+}-\mathrm{N}\right)$ and nitrate- $\mathrm{N}\left(\mathrm{NO}_{3}^{-}-\mathrm{N}\right)$ content in the "compacted", "compacted + DCD" and "non-compacted" soils was low ( $\leq 20 \mathrm{~kg} \mathrm{~N} / \mathrm{ha}$ ) throughout the trial (Fig. 2a and 2b). Soil mineral $\mathrm{N}$ contents were determined for all three treatments during trial 2. Soil $\mathrm{NH}_{4}^{+}-\mathrm{N}$ content increased rapidly 4 days following urine application, slowly 


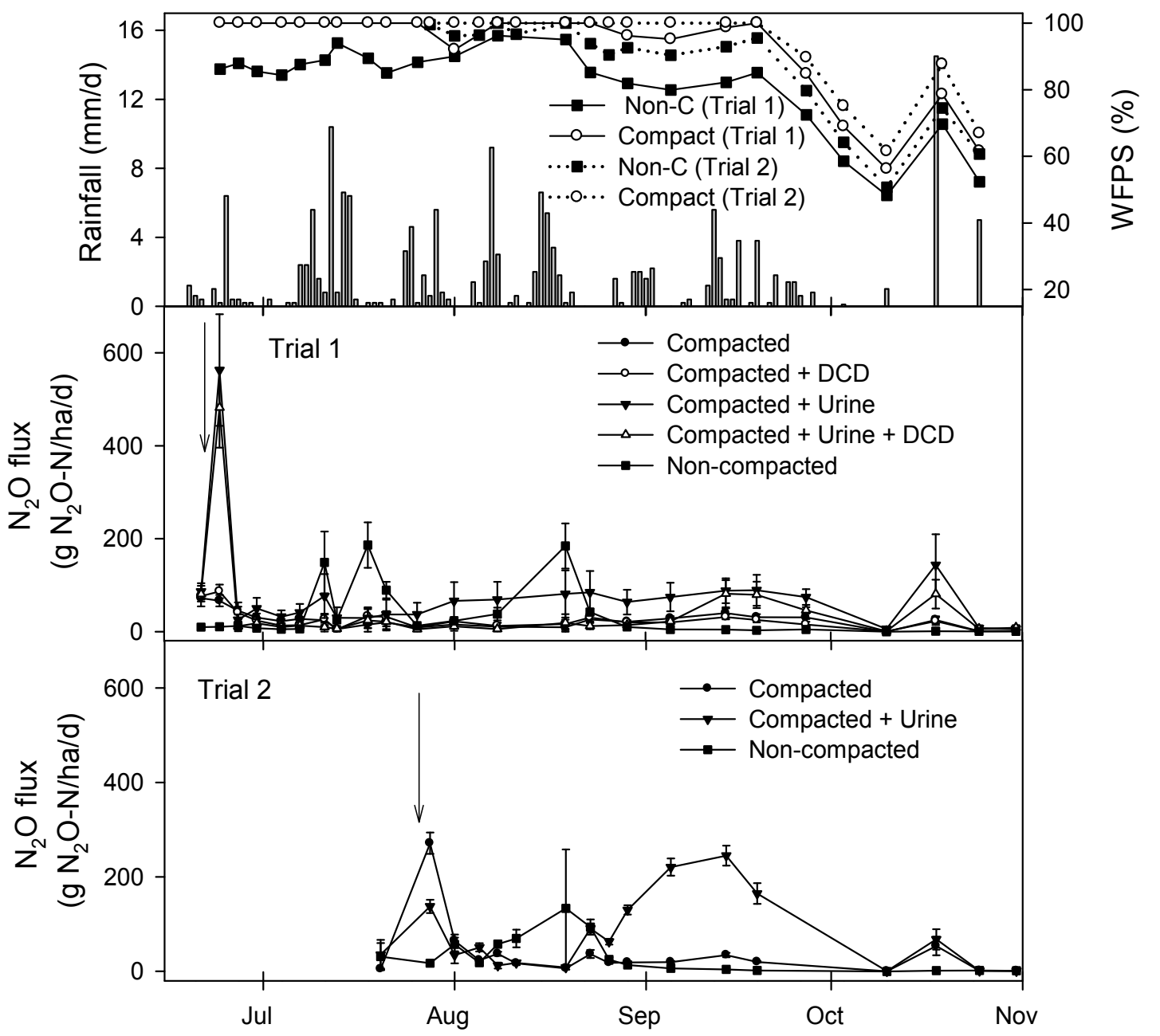

Figure 1. Rainfall (mm/day), water-filled pore space (WFPS) (\%) and $\mathrm{N}_{2} \mathrm{O}$ fluxes ( $\mathrm{g} \mathrm{N}_{2} \mathrm{O}-\mathrm{N} / \mathrm{ha} /$ day) measured during trial 1 and 2 in the winter and spring months of 2011. For WFPS, 'Non-C' refers to non-compacted soil. $\downarrow$ indicates time of application of compaction and urine treatments. Error bars $= \pm$ SEM.

returning to background levels within 2 months (Fig. 2c). Soil $\mathrm{NO}_{3}^{-}-\mathrm{N}$ levels increased in the urine treated soils three weeks following application, remaining high until the trial ceased when the paddock was to be cultivated (end of October: Fig. 2d). In contrast, $\mathrm{NH}_{4}^{+}-\mathrm{N}$ and $\mathrm{NO}_{3}^{-}-\mathrm{N}$ levels in the "compacted" and "non-compacted" treatments were consistently low throughout trial 2 (Fig. 2c and 2d).

\section{Nitrous oxide fluxes}

In trial $1, \mathrm{~N}_{2} \mathrm{O}$ fluxes were greatest from the "compacted + urine" and "compacted + urine + DCD" treatments immediately after urine application (563 and $482 \mathrm{~g}$ $\mathrm{N}_{2} \mathrm{O}-\mathrm{N} /$ ha/day, respectively: Fig. 1). Thereafter, fluxes declined, with the "compacted + urine" remaining stable at between $40-70 \mathrm{~g} \mathrm{~N} \mathrm{~N}_{2} \mathrm{O}-\mathrm{N} /$ ha/day for $c a .4$ months; the addition of DCD ensured fluxes were close to zero for $c a .2 \frac{1}{2}$ months before a small increase was observed. The "non-compacted" treatment exhibited periods of high flux activity throughout the trial, at times being greater than the fluxes measured from all other treatments. Fluxes from all five treatments declined to low levels by the end of the trial. Trial 2, initiated on 20 July, also showed a spike in $\mathrm{N}_{2} \mathrm{O}$ fluxes from the "compacted" and "compacted + urine" treatments immediately following treatments being imposed (Fig. 2). Approximately 1 month later, $\mathrm{N}_{2} \mathrm{O}$ fluxes from the "compacted + urine" treatment were elevated for 1 month before returning to low levels. As for trial 1, the non-compacted treatment produced $\mathrm{N}_{2} \mathrm{O}$ fluxes that were, at times, greater than from the "compacted" treatment. 


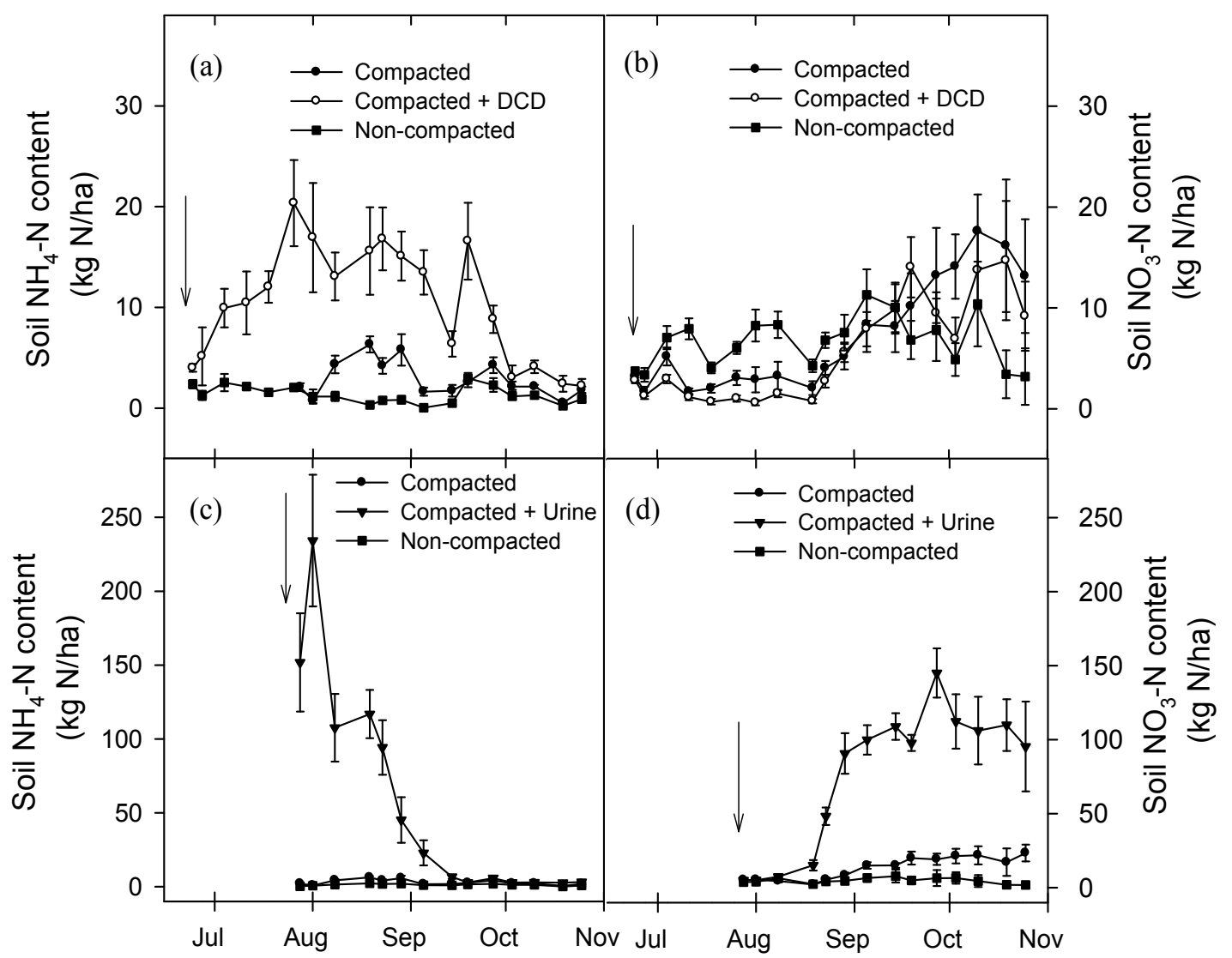

Figure 2. Soil mineral $\mathrm{N}$ concentrations following simulated winter grazing of a forage swede crop. Fig. 2a-b = Trial 1; Fig. $2 c-d$ $=$ Trial 2. $\downarrow$ indicates time of application of compaction and urine treatments. Note the different Y-axis scales used for Trials 1 and 2. Error bars $= \pm$ SEM.

Cumulative $\mathrm{N}_{2} \mathrm{O}$ losses for the "compacted + urine" treatment in both trials 1 and 2 were significantly greater than all other treatments $(\mathrm{P}<0.001$; Table 2$)$. In trial 1, cumulative losses from the non-compacted soil were significantly greater than from compacted soil $(\mathrm{P}<0.05)$, while cumulative losses from these two treatments were similar in trial 2.

The application of DCD significantly reduced $\mathrm{N}_{2} \mathrm{O}$ losses from the "compacted + urine" treatment by $50 \%$ in trial 1, whereas it had no effect on the "compacted" treatment (Table 2). The $\mathrm{N}_{2} \mathrm{O}$ emission factors for the deposited urine in trials 1 and 2 were not significantly different $(\mathrm{P}=0.76)$, at 3.0 and $3.3 \%$ of the applied $\mathrm{N}$, respectively, averaging $3.2 \%$ across both trials. DCD application significantly reduced $\mathrm{EF}_{3}$ to $0.9 \%(\mathrm{P}=0.03)$, equivalent to a $71 \%$ reduction in $\mathrm{N}_{2} \mathrm{O}$ emission from

Table 1. Physical data for soil pre- and post-compaction (mean $\pm S E M ; n=6$ ).

\begin{tabular}{lcccc}
\hline Treatment & Depth $(\mathrm{cm})$ & $\begin{array}{c}\text { Bulk density } \\
\left(\mathrm{g} / \mathrm{cm}^{3}\right)\end{array}$ & Macroporosity (\%) & Total porosity (\%) \\
\hline Non-compacted & $0-5$ & $1.00(0.01)$ & $16.5(0.6)$ & $62.3(0.5)$ \\
Non-compacted & $5-10$ & $1.22(0.03)$ & $11.9(1.2)$ & $54.1(1.3)$ \\
Compacted & $0-5$ & $1.12(0.02)$ & $8.8(0.2)$ & $57.7(0.7)$ \\
Compacted & $5-10$ & $1.21(0.02)$ & $12.9(0.8)$ & $54.2(0.7)$ \\
P-value for Non-compacted vs Compacted & & $* *$ & N* \\
$0-5 \mathrm{~cm}$ & & NS & NS & NS \\
$5-10 \mathrm{~cm}$ & & &
\end{tabular}


urine patches. At a paddock scale, the $\mathrm{N}_{2} \mathrm{O}$ emission from the swede crop over a 52-day period was $7.9 \mathrm{~kg}$ $\mathrm{N}_{2} \mathrm{O}-\mathrm{N} / \mathrm{ha}^{-1}$, which was reduced by $57 \%$ when DCD was applied; this was equivalent to a reduction from 5.2 to $2.2 \mathrm{~g} \mathrm{~N}_{2} \mathrm{O}-\mathrm{N} /$ cow/day.

\section{Discussion}

High $\mathrm{N}_{2} \mathrm{O}$ emission from the compacted, urine-treated soil was primarily due to urine being deposited onto wet soil. Urine supplies readily available $\mathrm{N}$ and causes the release of soil organic $\mathrm{C}$ by hydrolysing organic matter (Uchida et al. 2008), leading to increased $\mathrm{N}_{2} \mathrm{O}$ production when oxygen diffusion is restricted (Bhandral et al. 2007). Smith et al. (2008) found that total $\mathrm{N}_{2} \mathrm{O}$ losses from compacted plots with and without urine applied were equivalent to 7.7 and $2.2 \mathrm{~kg} \mathrm{~N} / \mathrm{ha}$, respectively. Ball et al. (2012) attributed a three-fold increase in $\mathrm{N}_{2} \mathrm{O}$ emissions from urine-treated pasture following compaction (trampling) to increased WFPS, aggregate destruction and suppression of grass growth. Although this study and others (e.g. Houlbrooke et al. 2009) have also shown changes in soil physical condition due to simulated compaction and pugging where urine was excluded, we observed significantly greater $\mathrm{N}_{2} \mathrm{O}$ emissions from the non-compacted soil in trial 1 and no difference in losses from non-compacted and compacted soil in trial 2.With WFPS often at $100 \%$, the compaction treatment probably stimulated complete denitrification, thereby favouring $\mathrm{N}_{2}$ production over $\mathrm{N}_{2} \mathrm{O}$ production (Dalal et al. 2003).

The estimated paddock scale emission of $\mathrm{N}_{2} \mathrm{O}$ from the winter forage crop was high, despite the urine $\mathrm{N}$ concentration being relatively low at $1.9 \mathrm{~g} \mathrm{~N} / \mathrm{L}$. Cattle urine $\mathrm{N}$ concentration is typically $6-7 \mathrm{~g} \mathrm{~N} / \mathrm{L}$ when the cattle are grazing pasture (de Klein et al. 2003; Menneer et al. 2008). The high emissions observed here may be a consequence of urine deposition onto compacted, poorly aerated soil that encourages denitrification (Menneer $e t$ al. 2005). The high grazing densities $\left(6.6 \mathrm{~m}^{2} \mathrm{crop} / \mathrm{cow} /\right.$ day) and high rates of urine deposition per unit area are also likely to increase paddock emissions. Smith et al. (2008) measured an $\mathrm{N}_{2} \mathrm{O}$ emission of $2.7 \mathrm{~kg} \mathrm{~N} /$ ha from a winter forage crop over a 5 -month period, which is less than a third than measured here. Whilst their urine-N application rate was higher $(387 \mathrm{~kg} \mathrm{~N} /$ ha), their calculated $\mathrm{EF}_{3}$ value was only $1.41 \%$ and it was assumed only $25 \%$ of the surface area was affected by urine, which was primarily due to a lower urine volume of $20 \mathrm{~L} / \mathrm{cow} /$ day compared to $60 \mathrm{~L} / \mathrm{cow} /$ day in the current study. Nitrous oxide losses measured from an autumn-winter grazed Southland pasture were even lower, at between 0.4 and $1.9 \mathrm{~kg} \mathrm{~N} 2 \mathrm{O}-\mathrm{N} /$ ha over three years (de Klein et al. 2006), perhaps due to the presence of pasture utilising some of the surplus urinary $\mathrm{N}$.

A single application of DCD within 1 day of grazing was effective at reducing $\mathrm{N}_{2} \mathrm{O}$ emissions from the "grazed" winter forage crop, due mainly to its impact on urine patches. In their study of a winter forage crop, Smith et al. (2008) found that DCD reduced $\mathrm{N}_{2} \mathrm{O}$ emissions per hectare by only $25 \%$, compared to the $57 \%$ calculated here. The difference in calculated effectiveness between these two studies primarily relates to the assumed paddock area affected by urine ( 25 vs. $90 \%$ for their and our studies, respectively). While our reduction in $\mathrm{N}_{2} \mathrm{O}$ emissions is based on experimental data where DCD was applied to a single urine patch and assumes no overlap of urine patches, DCD is likely to be as effective on areas where 2 or even 3 patches overlap, as Di et al. (2007) have shown that emissions can be reduced by $70 \%$ from urine applied at $1000 \mathrm{~kg} \mathrm{~N} / \mathrm{ha}$, which is five times the urine- $\mathrm{N}$ rate used in the current study.

In conclusion, while urine-affected, compacted winter forage soils can result in relatively large $\mathrm{N}_{2} \mathrm{O}$

Table 2. Cumulative nitrous oxide emissions ( $\mathrm{kg} \mathrm{N} / \mathrm{ha}$ ) from individual treatments, measured over 129 days (trial 1 ) and 95 days (trial 2), and associated emission factors $\left(\mathrm{EF}_{3}\right)$ for urine $( \pm \mathrm{DCD})$ treatments. Also shown is the mean $\mathrm{EF}_{3}$ value, calculated from the Compacted + Urine treatment, using results from both trials.

\begin{tabular}{|c|c|c|c|c|c|}
\hline \multirow[t]{2}{*}{ Treatment } & \multicolumn{2}{|l|}{ Trial 1} & \multicolumn{2}{|l|}{ Trial 2} & \multirow{2}{*}{$\begin{array}{l}\text { Mean } \\
\mathrm{EF}_{3}(\%)\end{array}$} \\
\hline & $\begin{array}{l}\text { Cumulative loss (kg } \\
\qquad \mathrm{N} / \mathrm{ha})\end{array}$ & $\mathrm{EF}_{3}(\%)$ & $\begin{array}{l}\text { Cumulative loss (kg } \\
\qquad \mathrm{N} / \mathrm{ha})\end{array}$ & $\begin{array}{l}\mathrm{EF}_{3} \\
(\%)\end{array}$ & \\
\hline Non-compacted & 4.04 & & 2.16 & & \\
\hline Compacted & 2.49 & & 2.53 & & \\
\hline Compaction + DCD & 2.42 & & & & \\
\hline Compaction + Urine & 8.23 & 3.0 & 8.94 & 3.3 & 3.2 \\
\hline Compaction + Urine + DCD & 4.08 & 0.9 & & & \\
\hline sed & 0.24 & 0.7 & 0.72 & & \\
\hline P-value & $P<0.001$ & $P=0.03$ & $P<0.001$ & & \\
\hline
\end{tabular}


losses, strategic use of DCD provides farmers with a management option for making significant reductions. Further research should examine timing and rate of DCD application, as this will influence its effectiveness on grazed winter forage crops.

\section{ACKNOWLEDGEMENTS}

David Stevens for providing estimates of $\mathrm{N}$ outputs from cattle and Neil Cox for statistical analysis. Funding was provided through a SFF project, jointly funded by the Ministry for Primary Industries (formerly MAF) and DairyNZ.

\section{REFERENCES}

Ball, B.C.; Cameron, K.C.; Di, H.J.; Moore, S. 2012. Effects of trampling of a wet dairy pasture on soil porosity and on mitigation of nitrous oxide emissions by a nitrification inhibitor, dicyandiamide. Soil Use and Management 28:194-201.

Bhandral, R.; Saggar, S.; Bolan, N.S.; Hedley, M.J. 2007. Transformation of nitrogen and nitrous oxide emission from grassland soils as affected by compaction. Soil \& Tillage Research 94: 482-492.

Dalal, R.C.; Wang, W.; Robertson, G.P.; Parton, W.J. 2003. Nitrous oxide emission from Australian agricultural lands and mitigation options: a review. Australian Journal of Soil Research 41: 165-195.

de Klein, C.A.M.; Barton, L.; Sherlock, R.R.; Li, Z.; Littlejohn, R.P. 2003. Estimating a nitrous oxide emission factor for animal urine from some New Zealand pastoral soils. Australian Journal of Soil Research 41: 381-399.

de Klein, C.A.M.; Smith, L.C.; Monaghan, R.M. 2006. Restricted autumn grazing to reduce nitrous oxide emissions from diary pastures in Southland, New Zealand. Agriculture, Ecosystems and Environment 112: 192-199.
Di, H.J.; Cameron, K.C.; Sherlock, R.R. 2007. Comparison of the effectiveness of a nitrification inhibitor, dicyandiamide, in reducing nitrous oxide emissions in four different soils under different climatic and management conditions. Soil Use and Management 23: 1-9

Hewitt, A.E. 2010. New Zealand Soil Classification. Third edition. Landcare Research Science Series No. 1. Manaaki Whenua Press, Lincoln, Canterbury. pp136.

Houlbrooke, D.J.; Paton, R.J.; Morton, J.D.; Littlejohn, R.P. 2009. Soil quality and plant yield under dryland and irrigated winter forage crops grazed by sheep or cattle. Australian Journal of Soil Research 47: 470-477.

Menneer, J.C.; Ledgard, S.;McLay, C.; Silvester, W. 2005. Animal treading stimulates denitrification in soil under pasture. Soil Biology \& Biochemistry 37: 1625-1629.

Menneer, J.C.; Ledgard, S.; Sprosen, M. 2008. Soil N process inhibitors alter nitrogen leaching dynamics in a pumice soil. Australian Journal of Soil Research 46: 323-331.

Ministry for the Environment 2012. New Zealand's Greenhouse Gas Inventory 1990-2010. Ministry for the Environment. ISSN: 1179-223X, Wellington, New Zealand.

Smith, L.C.; de Klein, C.A.M.; Monaghan, R.M.; Catto, W.D. 2008. The effectiveness of dicyandiamide in reducing nitrous oxide emissions from a cattlegrazed, winter forage crop in Southland, New Zealand. Australian Journal of Experimental Agriculture 48: 160-164.

Uchida, Y.; Clough, T.J.; Kelliher, F.M.; Sherlock, R.R. 2008. Effects of aggregate size, soil compaction, and bovine urine on $\mathrm{N}_{2} \mathrm{O}$ emissions from a pasture soil. Soil Biology \& Biochemistry 40: 924-931. 